\title{
ВЫДЕЛЕНИЕ И ОЦЕНКА СВОЙСТВ ПОЛИМИКТОВЫХ КОЛЛЕКТОРОВ НИЖНЕНУТОВСКОЙ ПОДСВИТЫ СЕВЕРО-ВОСТОЧНОГО ШЕЛЬФА САХАЛИНА МЕТОДАМИ ГИС
}

Соколова Т.Ф.*, Крылова М.В. *, Корабиинов В.Е.**

(* - Фугро-Джейсон, ** - ОАО "Венинефть")

Объектами изучения являются отложения нижненутовской подсвиты северо-восточного шельфа Сахалина. Коллекторы продуктивных пластов представлены тонким тередованием прослоев полимиктовых песчаников, алевролитов и глинистых разностей. Редко встречаются уплотненные прослои песчаников с карбонатным цементом.

Пестаники продуктивных горизонтов относятся к полимиктовым разностям и представлены кварцем (44.9\% по весу), калиевыми полевыми шпатами (16.4\%), альбитом (20.7\%), глинистыми минералами (каолинитом, хлоритом, иллитом и смектитом). Глинистые минералы присутствуют в цементирующей массе, и также в качестве вторичного материала, образовавшегося в результате процессов преобразования плагиоклазов. Наличие процессов вторичной глинизации приводит к образованию дополнительной пористости в скелете породы, которая в рассматриваемых коллекторах соизмерима по значению с межзерновой пористостью породы.

Бурение скважин осуществляется на соленой промывочной жидкости с добавлением соединений калия в условия п превьшения минерализации ПЖ над минерализацией пластовой воды. Давление столба жидкости в стволе скважины существенно превышает пластовое, что приводит к образованию глинистой корки на стенках скважины, формированию зоны проникновения фильтрата ПЖ и к образованио зоны кольматация. Осложнения в процессе бурения связаны с наличнем зон аномально высоких пластовых давлений (АВПД).

Каротаж в скважинах выполнен аппаратурой фирмы Шлюмберже. Комплекс ГИС включает следующие методы: гамма-метод, двухзондовый нейтрон-нейтронный, плотностной и акустнцеский методы, микрозонды, боковой и индукционный методы, каверномер и метод потенциалов собственной поляризацин.

Выделение коллекторов выполнено на качественном уровне по сужению диаметра скважины, пониженным показаниям гамма-каротажа, низким концентрациям тория, повышенным значениям интервального времени пробега продольной волны, пониженным значениями объемной плотности и положительным аномалиям на кривой потенциалов собственной поляризации (минерализащия пластовых вод ниже минерализации фильтрата ПЖ). При отсутствии надежных качественных признаков, выделение коллекторов выполнялось с учетом количественного критерия, обоснованного при анализе результатов исследованкя керна - граничного значення коэффициента пористости $\mathrm{K}_{\text {n,гp. }}=15 \%$.

Вылеление продуктивных интервалов выполнено путем нормализации расчетного значения удельного электрического согротивления полностъю водонасьпенной породы $\left(\rho_{\mathrm{Br}}=\mathrm{P}_{n} \cdot \rho_{\mathrm{B}}\right)$ и истинного сопротивления пласта $\rho_{\mathrm{II}}$, которое оценивалось по показаниям зонда электрометрии с наибольшим раднусом исследования.

Для оценки коэффищиентов пористости коллекторов использован комплекс плотностного и нейтрон-нейтронного методов, который позволяет выполнить определение коэффициентов общей пористости $K_{n}$ и объемного содержания глинистого матернала $\mathrm{K}_{\text {гл }}$ в нефте- и водонасыщенных коллекторах. В газонасыщенныг интервалах разреза производилась корректировка показаний методов за влияние газа.

Величина $K_{\mathrm{rлл}}$ использовалась для получения связей между показаниями интегрального ГК и ториевой компоненты с содержанием в породе глинистого вещества. Наличие этих связей позволяет производить оценку $\mathrm{K}_{\text {гл }}$ при отсутствии в комплексе ГИС плотностного каротажа и в скважинах, бурящихся с применением соединений калия.

Определения коэффициентов нефтегазонасыщенности выполнено традиционным способом Дахнова-Арqи с помощью удельного электрического сопротивления, которое оценивалось по показаниям глубинного зонда электрометрин.

Значения коэффициента пористости для коллекторов изменяются для интервала в диапазоне $0.15-0.30$, при среднем значенғи 0.22 ; объемное содержание глинистого вещества изменяется в диапазоне $0.12-0.65$, при среднем значении $\mathrm{K}_{\text {гл }}=0.32$. Значения коэффициентов насыщения, в целом, не высокие, что является особенностью рассматриваемых отложений, характеризующихся высоким содержанием глинистого материала, наличием вторичной глинизащия и присутствием коллекторов слонстого типа.

Выделенные коллекторы в изучаемом разрезе глинистые, с различными типами распределения глинистого материала, сложной структурой порового пространства, высоким содержанием остаточной воды и невысокой степенью насыщения углеводородами. Комплекс методов ГИС позволил выделить коллекторы в разрезах скважин и выполнить количественную интерпретацию в этих интервалах разреза. Повышение достоверности результатов интерпретации методов ГИС на вновь пробуренньг площадях в сложных полимиктовых отложениях нутовской подсвиты возможно при утоннении связей типа “керн-керн" за стет отбора и исследования образцов керна на этих ппощадях, уточнения минерализащии пластовых вод в продуктивных пластах, изучения температурного режима залежей, закономерностей изменения пластового давления с целью выделения зон с АВПД и с целью обоснования выбора оптимальньх условий вскрытия коллекторов в этих разрезах. 